\title{
Odia Language
}

National Cancer Institute

\section{Source}

National Cancer Institute. Odia Language. NCI Thesaurus. Code C154069.

An Indo-Aryan language that is spoken mostly in eastern India. 